\title{
Protocol \\ Purification and Characterization of Recombinant Expressed Apple Allergen Mal d 1
}

\author{
Julia A. H. Kaeswurm ${ }^{1}$, Bettina Nestl ${ }^{2}$, Sven M. Richter ${ }^{2}$, Max Emperle ${ }^{2}$ and Maria Buchweitz ${ }^{1, *(1)}$ \\ 1 Department of Food Chemistry, Institute of Biochemistry and Technical Biochemistry, University of Stuttgart, \\ 70569 Stuttgart, Germany; julia.kaeswurm@lc.uni-stuttgart.de \\ 2 Department of Technical Biochemistry, Institute of Biochemistry and Technical Biochemistry, \\ University of Stuttgart, 70569 Stuttgart, Germany; bettina.nestl@ibtb.uni-stuttgart.de (B.N.); \\ sven.richter@ibtb.uni-stuttgart.de (S.M.R.); max.emperle@ibtb.uni-stuttgart.de (M.E.) \\ * Correspondence: maria.buchweitz@lc.uni-stuttgart.de; Tel.: +49-711-68569231
}

Citation: Kaeswurm, J.A.H.; Nestl, B.; Richter, S.M.; Emperle, M.; Buchweitz, M. Purification and Characterization of Recombinant Expressed Apple Allergen Mal d 1. Methods Protoc. 2021, 4, 3. https://doi.org/10.3390/ mps4010003

Received: 20 November 2020 Accepted: 23 December 2020 Published: 27 December 2020

Publisher's Note: MDPI stays neutral with regard to jurisdictional claims in published maps and institutional affiliations.

Copyright: () 2020 by the authors. Licensee MDPI, Basel, Switzerland. This article is an open access article distributed under the terms and conditions of the Creative Commons Attribution (CC BY) license (https: / / creativecommons.org/ licenses/by/4.0/).

\begin{abstract}
Mal d 1 is the primary apple allergen in northern Europe. To explain the differences in the allergenicity of apple varieties, it is essential to study its properties and interaction with other phytochemicals, which might modulate the allergenic potential. Therefore, an optimized production route followed by an unsophisticated purification step for Mal d 1 and respective mutants is desired to produce sufficient amounts. We describe a procedure for the transformation of the plasmid in competent $E$. coli cells, protein expression and rapid one-step purification. r-Mal d 1 with and without a polyhistidine-tag are purified by immobilized metal ion affinity chromatography (IMAC) and fastprotein liquid chromatography (FPLC) using a high-resolution anion-exchange column, respectively. Purity is estimated by SDS-PAGE using an image-processing program (Fiji). For both mutants an appropriate yield of r-Mal d 1 with purity higher than $85 \%$ is achieved. The allergen is characterized after tryptic in gel digestion by peptide analyses using HPLC-MS/MS. Secondary structure elements are calculated based on CD-spectroscopy and the negligible impact of the polyhistidine-tag on the folding is confirmed. The formation of dimers is proved by mass spectrometry and reduction by DTT prior to SDS-PAGE. Furthermore, the impact of the freeze and thawing process, freeze drying and storage on dimer formation is investigated.
\end{abstract}

Keywords: apple allergy; Mal d 1; recombinant expression in E. coli; purification; high-resolution anion-exchange column; CD spectra; tryptic in gel digestion; peptide identification; stability; dimer formation

\section{Introduction}

The allergen Mal d 1 is the primary apple allergen in northern Europe [1]. Due to the great structural similarity between the allergen Bet $\mathrm{v} 1$ in birch and Mal $\mathrm{d} 1$ in apple, the immune system can only distinguish between the two proteins with difficulty [2-4]. Therefore, about $50-70 \%$ of people affected by birch pollen allergy develop a cross-allergy to apple (Malus domestica) during their lifetime [1,5,6]. Although the $17.5 \mathrm{kDa}$ large allergen Mal d 1 is heat-labile and proteases break it down during gastric digestion, [7] the symptoms during consumption, such as breathing difficulties, itching and burning of the mucous membranes of the mouth or tongue (Oral Allergy Syndrome) mean that an estimated 2 million affected people in Germany alone generally avoid eating fresh apples $[1,5]$.

It is striking that the allergenic potential, which up to now has only been examined diagnostically on the effect level after oral provocation, skin prick tests or immunochemical testing with allergy sera, clearly differs between different apple varieties [8,9]. However, these differences could not be sufficiently correlated with the variety- or cultivation-related differences in the Mal d 1 content so that the absolute content of Mal d 1 cannot be the sole cause of an apple's allergenic potential [10-12]. An interaction of Mal d 1 with other 
phytochemicals reducing the allergenic potential has been postulated [13-15], but the structural requirements for the phytochemicals, as well as the interaction mechanisms, are still unknown. To investigate interaction strength, kinetics, and desired reaction conditions for different phytochemicals, purified Mal d 1 is a prerequisite. Purification by immobilized metal ion affinity chromatography (IMAC) for proteins exhibiting a C-terminal His-Tag might be a quick procedure to obtain high purities. Nevertheless, in lots of experimental settings, this additional feature is perturbing. Therefore, a process to purify the protein without a His Tag is required as well. Commonly time-consuming multi-step purification methods, including FPLC (fast protein liquid chromatography) based on a combination of different separation principles like ion exchange (IEC), hydrophobic interaction and size exclusion chromatography, is used [16-18].

In contrast, in this manuscript the development of a rapid method to produce and purify sufficient amounts of r-Mal d 1 with and without a polyhistidine-tag in high purity for further experiments is described.

\section{Experimental Design}

The production protocol for r-Mal d 1 described here is divided into three parts, of which one is a protein purification step (Figure 1). After plasmid transformation in Escherichia coli (E. coli), the protein is expressed in the host cells, and the harvested cells are lysed by pressure. For the purification of the clear cell lysate containing r-Mal d 1 with a Cterminal polyhistidine-tag (r-Mal d 1-His), a HisTrap ${ }^{\mathrm{TM}} \mathrm{FF}$ column is employed, performing IMAC. To purify the clear cell lysate with r-Mal d 1, a chromatographic system, the ÄKTA purifier FPLC system, and a high-resolution anion exchange column the TOYOPEARL ${ }^{\mathrm{TM}}$ GigaCap Q-650M (IEC) are essential to perform this purification. However, no additional steps are required to obtain pure r-Mal d 1 after this step.

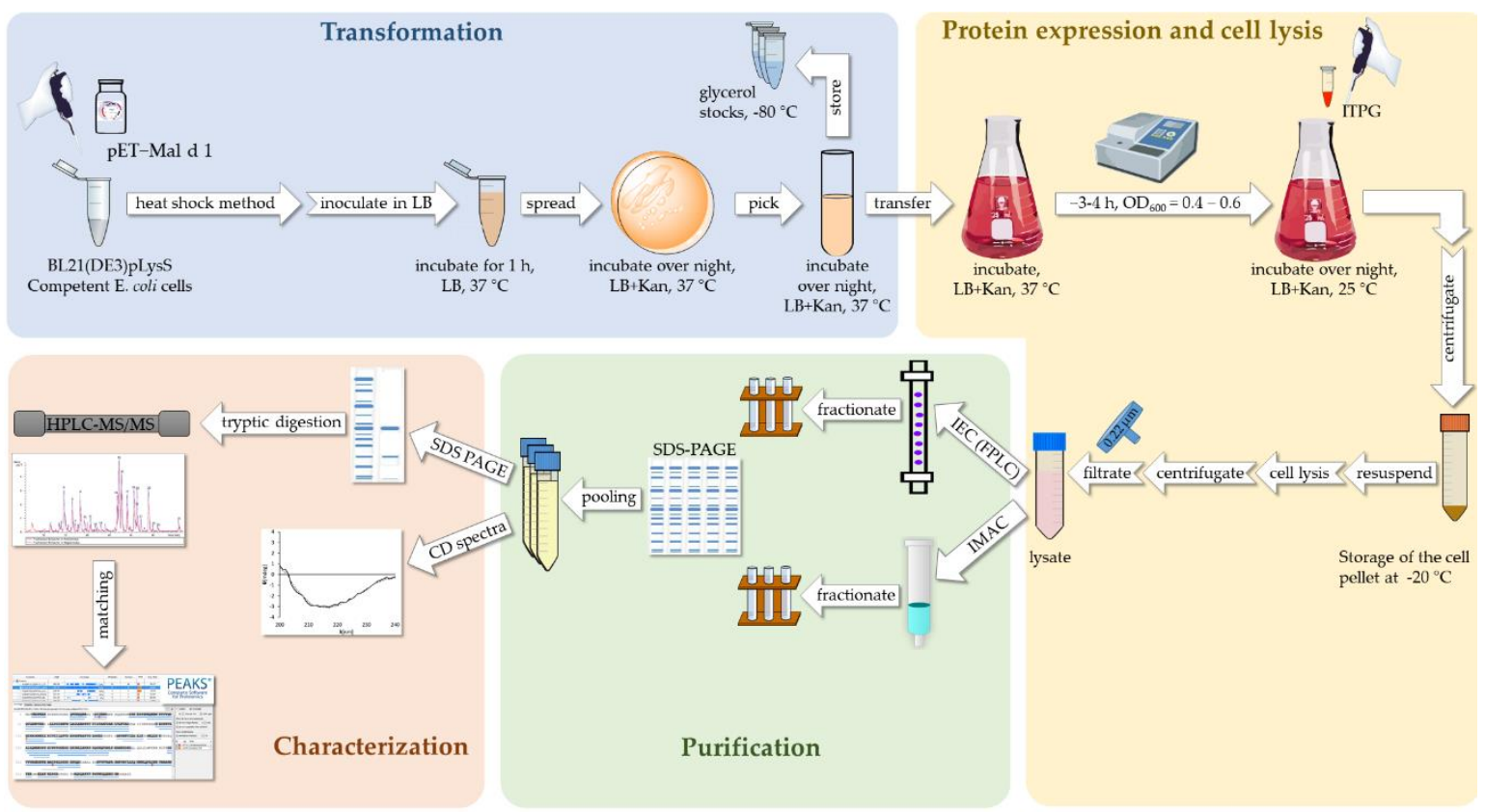

Figure 1. Purification and characterization workflow including plasmid transformation, r-Mal d 1 expression, purification, and characterization. Kan, Kanamycin; OD, optical density; ICE, ion exchange chromatography; IMAC, immobilized metal ion affinity chromatography; $\mathrm{CD}$, circular dichroism.

\subsection{Materials}

- $\quad$ Plasmid DNA in a pET-28b(+) vector with resistance against kanamycin, cloning sites are NcoI (CCATGG) and XhoI (CTCGAG), insert size is $485 \mathrm{bp}$ (Mal d 1), $488 \mathrm{bp}$ (Mal d 1-His), (BioCat GmbH, Heidelberg, Germany, Lot: MF72741) The amino acid sequence 
for Mal d 1 is according to the protein Q9SYW3 found in UniProt database, and the gene codon was optimized for expression in E. coli. For the polyhistidine variant, some valine-alanine interchanges were performed;

- Escherichia coli BL21 star (DE3)pLysS (ThermoFisher Scientific, Waltham, MA, USA);

- Potassium chloride (Sigma-Aldrich, Taufkirchen, Germany)

- Magnesium chloride hexahydrate (Sigma-Aldrich, Taufkirchen, Germany);

- Sodium chloride (Sigma-Aldrich, Taufkirchen, Germany)

- Tris(2-carboxyethyl)phosphine hydrochloride (TCEP) (Sigma-Aldrich, Taufkirchen, Germany);

- Imidazole (Sigma-Aldrich, Taufkirchen, Germany);

- Glycerol (Sigma-Aldrich, Taufkirchen, Germany);

- $\quad$ Tryptone (Fisher Scientific, Waltham, MA, USA);

- Yeast Extract (Fisher Scientific, Waltham, MA, USA);

- $\quad$ Lysogeny broth (LB) Lennox agar, granulated (Fisher Scientific, Waltham, MA, USA);

- Kanamycin (VWR International, Radnor, PA, USA);

- Isopropyl-D-1-thiogalactopyranoside (IPTG) (Fisher Scientific, Waltham, MA, USA);

- $\quad$ Tris hydrochloride (Tris-HCl) (Fisher Scientific, Waltham, MA, USA);

- Urea (Invitrogen, Carlsbad, CA, USA);

- $\quad$ Page Ruler Prestained Protein Ladder (Serva Dual Color Protein Standard III, Heidelberg, Germany);

- $\quad$ SERVAGel ${ }^{\mathrm{TM}}$ TG PRiME ${ }^{\mathrm{TM}} 4-20 \%, 15$ sample wells (Serva, Heidelberg, Germany, Lot V200051).

\subsection{Equipment}

- $\quad$ Autoclave Getinge sterilizer (Getinge AB, Göteborg, Sweden)

- Emulsiflex-C5 (Avestin, Ottawa, ON, Canada);

- $\quad$ ÄKTA purifier 10 (GE Healthcare Biosciences AB, Uppsala, Sweden);

- HisTrap ${ }^{\mathrm{TM}} \mathrm{FF}$, Ni Sepharose ${ }^{\mathrm{TM}} 6.5 \mathrm{~mL}$ (GE Healthcare, Buckinghamshire, UK);

- TOYOPEARL ${ }^{\mathrm{TM}}$ SuperQ-650S, strong anion exchange chromatography resin, SkillPak ${ }^{\mathrm{TM}} 5 \mathrm{~mL}$ columns, particle size distribution 20-50 $\mu \mathrm{m}$ (Tosoh Bioscience $\mathrm{GmbH}$, Griesheim, Germany);

- TOYOPEARL ${ }^{\mathrm{TM}}$ GigaCap Q-650M, strong anion exchange chromatography resin, SkillPak ${ }^{\mathrm{TM}} 5 \mathrm{~mL}$ columns, particle size distribution and 50-100 $\mu \mathrm{m}$ (Tosoh Bioscience $\mathrm{GmbH}$, Griesheim, Germany);

- $\quad$ Non-sterile polyethersulfon syringe filter, $0.2 \mu \mathrm{m}$ (VWR, Radnor, PA, USA);

- $\quad$ Sterile polyethersulfon syringe filter, $0.2 \mu \mathrm{m}$ (VWR, Radnor, PA, USA);

- Incubation shaker New Brunswick ${ }^{\mathrm{TM}}$ Excella $^{\circledR}$ E24/E24R (Eppendorf, Hamburg, Germany);

- Viva spin Amicon Ultra-15 centrifugal filters, 10K cutoff (Millipore, Burlington, MA, USA);

- Labconco Freezone 12 Liter Console Freeze Dry System (Freeze-drying) (Labconco, Kansas City, MO, USA);

- $\quad$ Centrifuge Beckman Avanti J-26S XP (Beckman Coulter, Brea, CA, USA);

- Visible Spectrophotometer (JASCO, Easton, MD, USA; Cat. no.: V-730) for optical density (OD) determination;

- BMG reader SPECTROstar Nano equipped with an LVis Plate (680-101) and software version 5.50, and MARS version 3.33 for data analyses respectively (BMG Labtech; Ortenberg, Germany);

- GenPure UV/UF CAD plus Ultrapure Water Purification System (Thermo Fisher Scientific, Waltham, MA, USA);

- Thermomixer comfort (Eppendorf AG, Hamburg, Germany);

- SDS PAGE chamber Peqlab PerfectBlue Twin S, model 45-1010 (VWR, Radnor, PA, USA);

- $\quad$ SDS Gels SERVAGel TG PRiME, 4-12\% (Serva, Heidelberg, Germany); 
- J-815 circular dichroism spectrophotometer (Jasco Corporation, Tokyo, Japan) fitted with a PTC-423S Peltier-type single-position cell holder (Jasco; Essex, UK);

- Quartz cuvette with $0.1 \mathrm{~mm}$ path length (HellmaAnalytik, Mülheim, Germany);

- YMC-Triart C18 column (Cat. No. TA12S03-15; pore $12 \mathrm{~nm}$, particle $3 \mu \mathrm{m}, 150 \mathrm{~mm}$ length $\times 0.3 \mathrm{~mm}$ internal diameter);

- M3 MicroLC system (Sciex, Darmstadt, Germany);

- TripleTOFTM 6600 (Sciex, Darmstadt, Germany) coupled to the LC system by a DuoSpray $^{\mathrm{TM}}$ Ion Source (Sciex).

\section{Procedure}

\subsection{Preparation of Solutions}

Use ultrapure water to prepare all the solutions in the protocol. Make liquid Lennox Broth by dissolving $10 \mathrm{~g}$ tryptone, $5 \mathrm{~g} \mathrm{NaCl}$, and $5 \mathrm{~g}$ yeast extract in $1 \mathrm{~L}$ water. Autoclave the liquid LB and let it cool to room temperature. To prepare solid LB agar plates, add $15 \mathrm{~g}$ of agar per $1 \mathrm{~L}$. For bacteria culture autoclave the broth and cool before adding $25 \mu \mathrm{g} / \mathrm{mL}$ sterile-filtered kanamycin and the transformed E. coli. For cell lysis steps and purification, prepare the following buffers:

- $100 \mathrm{mM}$ Tris Cl pH 7.5, containing $100 \mathrm{mM} \mathrm{NaCl}$;

- $100 \mathrm{mM}$ Tris $\mathrm{Cl} \mathrm{pH} \mathrm{7.5,} \mathrm{containing} 100 \mathrm{mM} \mathrm{NaCl}$ and $10 \mathrm{mM}$ imidazole;

- $100 \mathrm{mM}$ Tris $\mathrm{Cl}$ pH 7.5, containing $100 \mathrm{mM} \mathrm{NaCl}$ and $100 \mathrm{mM}$ imidazole;

- $20 \mathrm{mM}$ Tris $\mathrm{Cl}, \mathrm{pH} 7.5$ containing $1 \mathrm{M} \mathrm{NaCl}$;

- $100 \mathrm{mM}$ phosphate buffer $\mathrm{pH}$ 7.5;

- $1 \mathrm{M}$ urea buffer, supplemented with $166.7 \mathrm{mM}$ thiourea and $8 \mathrm{mM}$ Tris $\mathrm{Cl}, \mathrm{pH} 8$.

3.2. Expression of $r$-Mal $\mathrm{d} 1$ and $r$-Mal d 1-His

3.2.1. Transformation of pET-Mal d 1 Plasmid into Competent E. coli Cells

- The transformation is performed using the Heat Shock Method [19]

- To transform the plasmid into E. coli, thaw the frozen cells of competent BL21(DE3)pLysS $(50 \mu \mathrm{L})$ on ice, add $2 \mu \mathrm{L}$ of the plasmid $(0.1 \mathrm{ng} / \mathrm{mL})$ to the cells and mix gently.

- Incubate the mixture on ice for $30 \mathrm{~min}$ and then heat the tubes for $45 \mathrm{~s}$ in a thermo shaker at $42{ }^{\circ} \mathrm{C}$ and $180 \mathrm{rpm}$ to enable the transformation of plasmid into the cells.

- After heating, place the tubes on ice for $2 \mathrm{~min}$, inoculate the transformed bacteria into $500 \mu \mathrm{L}$ of liquid LB media without any antibiotics and incubate the cells for $1 \mathrm{~h}$ at $37^{\circ} \mathrm{C}$ and $180 \mathrm{rpm}$.

- Centrifuge the cell suspension, dispose the supernatant, resuspend the transformed cells in $200 \mu \mathrm{L}$ LB media and spread the cells on solid LB agar plates containing $25 \mu \mathrm{g} / \mathrm{mL}$ kanamycin, and keep the plates overnight in the incubator at $37^{\circ} \mathrm{C}$.

3.2.2. Expression of Mal d 1 Protein by the Transformed E. coli

- Pick a colony, inoculate into $5 \mathrm{~mL}$ liquid LB and incubate at $37^{\circ} \mathrm{C}$ and $180 \mathrm{rpm}$ overnight.

- Add an aliquot of $600 \mu \mathrm{L}$ of this starting culture to a $2 \mathrm{~L}$ no baffled flask containing $600 \mathrm{~mL}$ LB medium supplemented with $25 \mu \mathrm{g} / \mathrm{mL}$ kanamycin. Incubate flasks for each mutant at $37^{\circ} \mathrm{C}$ and $180 \mathrm{rpm}$ until an optical density (OD600) of 0.4-0.6 is reached.

- Start the overexpression of $\mathrm{r}-\mathrm{Mal} \mathrm{d} 1$ by adding $0.5 \mathrm{mM}$ isopropyl $\beta$-D-1thiogalactopyranoside (IPTG) and incubate overnight at $25^{\circ} \mathrm{C}$ and $180 \mathrm{rpm}$.

- After cell harvest by centrifugation at $4{ }^{\circ} \mathrm{C}(8980 \times g, 20 \mathrm{~min})$, the washed cell pellets can be stored at $-20^{\circ} \mathrm{C}$ until further use.

\subsubsection{Cell Lyses}

- Resolve the cell pellet $(200 \mathrm{mg} / \mathrm{mL})$ in $20 \mathrm{mM}$ Tris buffer $\mathrm{pH} 7.5$, disrupt physically three times with an EmulsiFlex ( $>600$ bar) in a cooling chamber and centrifuge (30 min, $\left.40,000 \times g, 4^{\circ} \mathrm{C}\right)$. 
- Filter the supernatant (filter, $0.2 \mu \mathrm{m}$ ) and use the lysate immediately for purification by immobilized metal ion affinity chromatography (IMAC) on a HisTrap ${ }^{\text {TM }}$ FF (r-Mal d 1-His) or by ion exchange chromatography (IEC) on a TOYOPEARLTM SkillPakTM column (r-Mal d 1).

\subsection{Purification of $r$-Mal $d 1$}

3.3.1. Purification of r-Mal d 1-His by Immobilized Metal ion Affinity Chromatography (IMAC)

- Add one column volume $(\mathrm{CV}, 5 \mathrm{~mL})$ lysate on a Tris buffer conditioned HisTrap ${ }^{\mathrm{TM}}$ FF column and wash with three CVs of Tris buffer (100 mM Tris. $\mathrm{Cl}$ buffer $\mathrm{pH} 7.5$ containing $100 \mathrm{mM} \mathrm{NaCl}$ ).

- Eluate with three CVs of Tris buffer containing $10 \mathrm{mM}$ imidazole, followed by five CVs Tris buffer containing $100 \mathrm{mM}$ imidazole and collect fractions corresponding to the column volume.

- Check the purity by SDS-PAGE gel analysis and combine the respective fractions with a r-Mal d 1 purity higher than $85 \%$.

3.3.2. Purification of r-Mal d 1 by Ion-Exchange Chromatography (IEC)

- Add $5 \mathrm{~mL}$ lysate (corresponds to $1 \mathrm{~g}$ cell pellet) on an equilibrated TOYOPEARLTM SuperQ-650S or GigaCap Q-650M SkillPakTM and eluate with a flow of $2 \mathrm{~mL} / \mathrm{min}$ with $1 \mathrm{M} \mathrm{NaCl}$ in $20 \mathrm{mM}$ Tris buffer, $\mathrm{pH} 7.5$ (eluent $\mathrm{B}$ ) using the gradients 4 or 5 (defined in Table 1; run 5, dilute $2.5 \mathrm{~mL}$ lysate with $2.5 \mathrm{~mL} 20 \mathrm{mM}$ Tris buffer to check for overloading in run 1-4).

- Collect the fractions according the UV absorption, check purity by SDS-PAGE gel analysis and combine all fractions with a r-Mal d 1 purity higher than $85 \%$, exchange buffer if required and store in aliquots at $-20^{\circ} \mathrm{C}$.

Table 1. Purification of r-Mal d 1 by ion-exchange chromatography.

\begin{tabular}{cccc}
\hline Run & Lysate $[\mathrm{mL}]$ & \multicolumn{1}{c}{ Column } & Gradient $^{\mathbf{1}}$ \\
\hline 1 & 5 & TOYOPEARL $^{\mathrm{TM}}$ SuperQ-650S & linear, $1.5 \mathrm{~mL} / \mathrm{min}, 0$ to $100 \%$ B for $15 \mathrm{CVs}$ \\
2 & 5 & TOYOPEARL $^{\mathrm{TM}}$ GigaCap Q-650M & linear, $2 \mathrm{~mL} / \mathrm{min}, 0$ to $100 \% \mathrm{~B}$ for $20 \mathrm{CVs}$ \\
3 & 5 & TOYOPEARL $^{\mathrm{TM}}$ GigaCap Q-650M & linear, $2 \mathrm{~mL} / \mathrm{min}, 0$ to $100 \% \mathrm{~B}$ for $25 \mathrm{CVs}$ \\
4 & 5 & TOYOPEARL $^{\mathrm{TM}}$ GigaCap Q-650M & stepwise, $2 \mathrm{~mL} / \mathrm{min}, 13 \% \mathrm{~B}$ for $5 \mathrm{CV}, 100 \%$ for $5 \mathrm{CVs}$ \\
5 & 2.5 & TOYOPEARL $^{\mathrm{TM}}$ GigaCap Q-650M & stepwise, $2 \mathrm{~mL} / \mathrm{min}, 10 \% \mathrm{~B}$ for $5 \mathrm{CV}, 100 \%$ for $5 \mathrm{CVs}$ \\
\hline
\end{tabular}

${ }^{1} \mathrm{~A}$, equilibration buffer $20 \mathrm{mM}$ Tris. $\mathrm{Cl}$, pH 7.5; B, elution buffer $1 \mathrm{M} \mathrm{NaCl}$ in $20 \mathrm{mM}$ Tris.Cl, pH 7.5; CV, column volume $5 \mathrm{~mL}$.

The respective chromatograms, indicating the fractions are provided in Figure 2. 

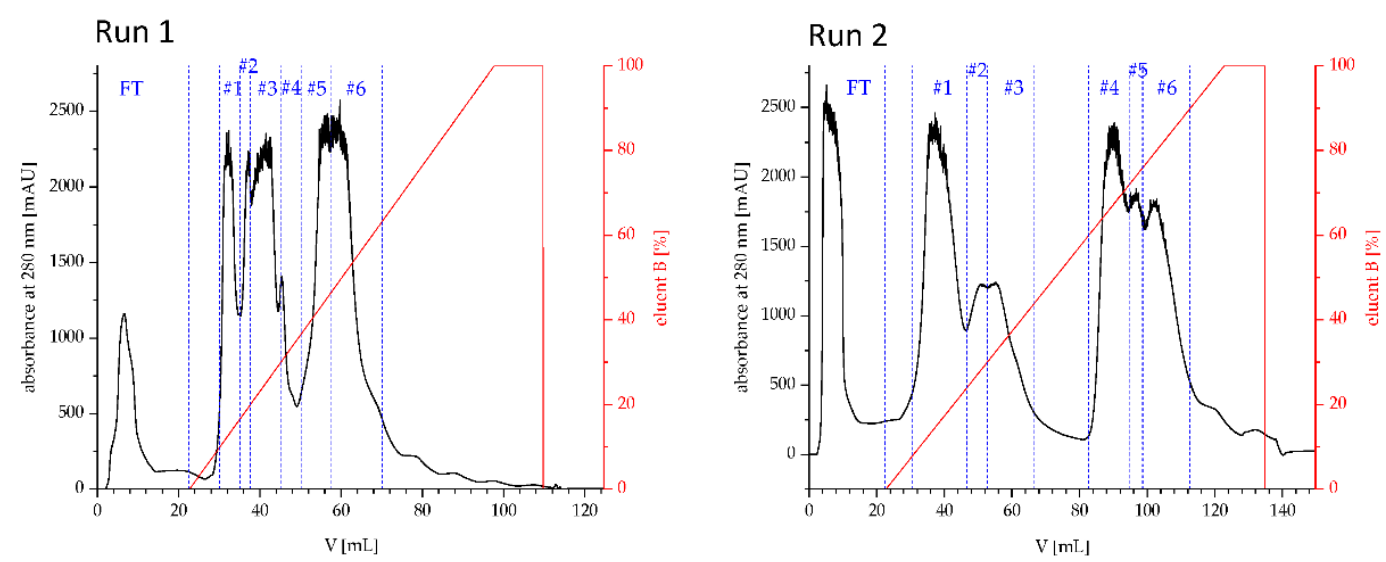

Run 3

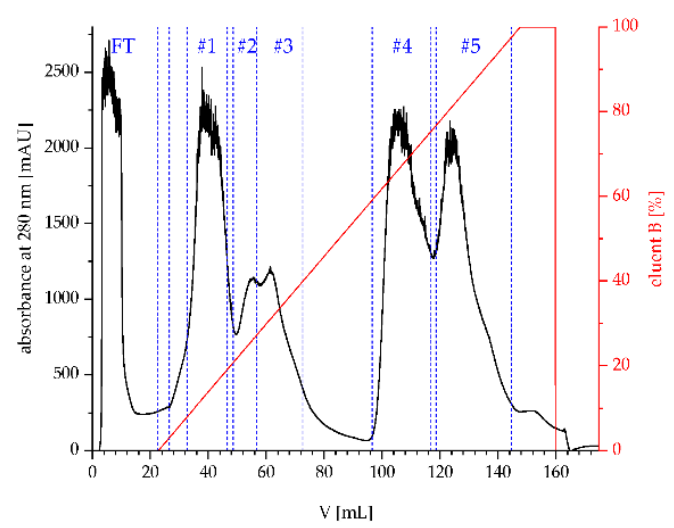

Run 4

Run 5
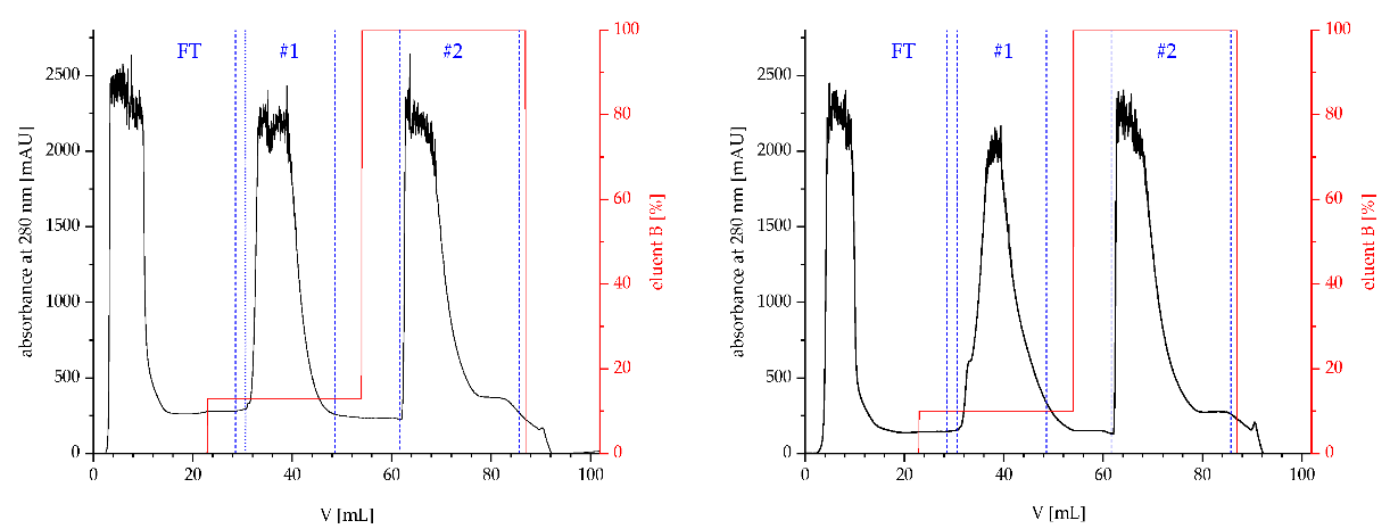

Figure 2. UV-chromatograms of run 1 to 5 , including \% B eluent (1 M NaCl in $20 \mathrm{mM}$ Tris. $\mathrm{Cl}$ buffer). The collected fractions (\#), which were pooled after SDS-PAGE gel analysis are indicated. To increase purity of Mal d 1 in run 3, sub-fractions of small volume were collected and discarded.

\section{Expected Results}

4.1. Quantity and Purity of the r-Mal d 1-His and r-Mal d 1

Pooled fraction volumes and protein concentrations for IMAC and IEC purification are shown in Table 2. To evaluate the purity and to identify the r-Mal d 1, $10 \mu \mathrm{L}$ of the pooled fractions was mixed with $40 \mu \mathrm{L}$ millipore water and $12.5 \mu \mathrm{L}$ SDS Laemmli sample buffer (fourfold concentrated), denaturized at $95^{\circ} \mathrm{C}$ and separated on SDS-PAGE gel, which was stained with Coomassie Brilliant Blue. After washing in aqueous acidic isopropanol $(80 / 10 / 10, v / v / v)$, the gels were scanned, and the purity was evaluated by 
Fiji [20]. If required, the bands were used for in-gel tryptic digestion (Figure 3). The fraction of the IMAC clean up eluted with $10 \mathrm{mM}$ imidazole is of lower r-Mal d 1-His concentration $(10.4 \mathrm{mg} / \mathrm{mL})$ and less purity (65\% r-Mal d 1-His) than the fraction with $100 \mathrm{mM}$ imidazole (14.4 $\mathrm{mg} / \mathrm{mL}$ and 85\% r-Mal d1-His) (Table 2, Figure A1).

Table 2. Fractions of purified r-Mal d 1 obtained with different methods.

\begin{tabular}{|c|c|c|c|}
\hline Run & Volume $^{1}[\mathrm{~mL}]$ & Concentration ${ }^{1}[\mathrm{mg} / \mathrm{mL}]$ & Yield Mal d $1^{2}$ [mg/Clean Up Step] \\
\hline IMAC\#1 ${ }^{3}$ & 12.5 & 10.4 & $130^{5}$ \\
\hline IMAC\#2 4 & 25 & 14.4 & $360^{5}$ \\
\hline 1 & 5 & 2.9 & $14.5^{6}$ \\
\hline 2 & 16 & 2.0 & $32.0^{6}$ \\
\hline 3 & 14 & 3.0 & $42.0^{6}$ \\
\hline 4 & 18 & $2.9^{7}$ & $52.2^{6}$ \\
\hline 5 & 18 & $1.3^{7}$ & $23.4^{8}$ \\
\hline
\end{tabular}

${ }^{1}$ Protein volume and concentration of pooled fractions containing Mal d 1 with a purity higher than $85 \%$ determined by measuring absorption at $280 \mathrm{~nm}$ with $\varepsilon 0.844 \mathrm{mg} / \mathrm{mL}$ [https://web.expasy.org/cgi-bin/protparam/ protparam1?P43211@noft@] (Spectrostar nano, BMG Labtech, Ortenberg); ${ }^{2}$ provided a Mal d 1 purity of 85\%; ${ }^{3}$ IMAC, fraction eluted with $10 \mathrm{mM}$ imidazole; ${ }^{4} \mathrm{IMAC}$, fraction eluted with $100 \mathrm{mM}$ imidazole; ${ }^{5}$ yield for $8 \mathrm{~g}$ cell pellet used in one clean up step, ${ }^{6}$ yield for $1 \mathrm{~g}$ cell pellet used in one clean up step; ${ }^{7}$ without dimerization purity is around $90 \%,{ }^{8}$ yield for $0.5 \mathrm{~g}$ cell pellet used in one clean up step.

The r-Mal d 1 without an additional polyhistidine-tag was purified on a strong anionexchange chromatography raisin. The high-resolution SuperQ-650S SkillPak ${ }^{\mathrm{TM}}$ usually contains High Capacity Ion Exchanger with a particle size of $35 \mu \mathrm{m}$. The GigaCap Q-650M SkillPak ${ }^{\mathrm{TM}}$ is filled with an Ultra High Capacity Ion Exchanger polymer-modified resin with a larger content of coupled ionic groups. Therefore, increased particle size is sufficient $(75 \mu \mathrm{M})$, permitting higher flow rates. The first runs showed that TOYOPEARL ${ }^{\mathrm{TM}}$ GigaCap Q-650M performed somewhat better (Figure 3, run 1 vs. run 2); therefore, the procedure was optimized exclusively for this column (Table 1). Using a stepwise gradient (run 4) slightly increased the volume of fraction containing r-Mal $\mathrm{d} 1$ with a purity higher than $85 \%$ but mainly shortened the procedure to $40 \mathrm{~min}$ (Figure 2, Table 1). The r-Mal d 1 was concentrated in fraction \#1 (Figure 3). However, negligible amounts of r-Mal d 1 were also found in the flow-through and fraction \#2. The purity of the fractions was estimated by using an image-processing program (Fiji) [20]. The fractions used for SDSPAGE gel analysis immediately after clean-up (run 4 and 5 \#1 fresh) showed a Mal d 1 purity higher than $85 \%$ (Figure 4 ) with 3-4 impurities, below 5\%. The SkillPak ${ }^{\mathrm{TM}}$ column's $^{\prime}$ optimal loading volume is $5 \mathrm{~mL}$ lysate obtained from $1 \mathrm{~g}$ cells pellet. Lower amounts do not improve purity or yield. TOYOPEARL ${ }^{\mathrm{TM}}$ GigaCap Q-650M are available in greater dimensions enabling possibilities for upscaling.
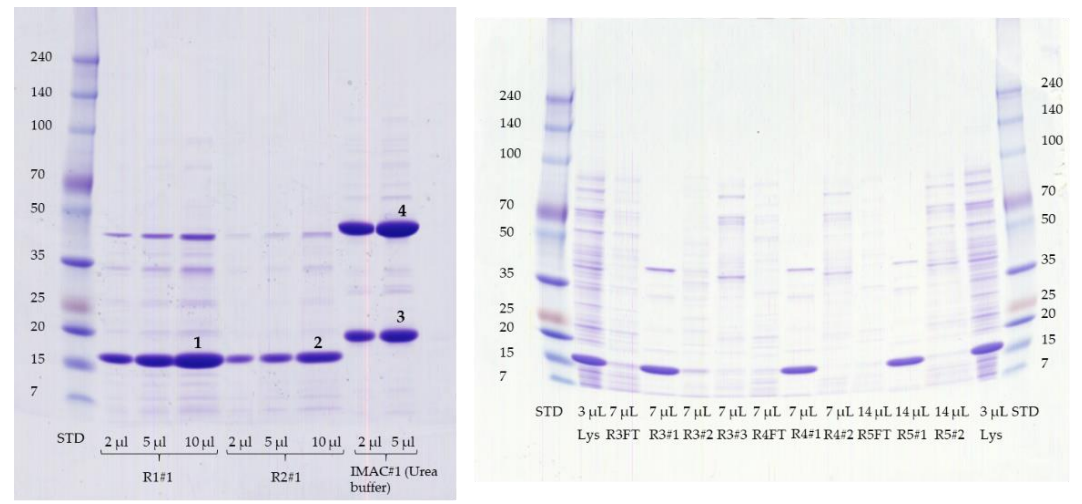

Figure 3. SDS-PAGE gels for pooled stored $\left(-20^{\circ} \mathrm{C}\right)$ fractions (\#), lysate (Lys) and FT (flow-through) indicated in Figure 1 of run (R) 1 and 2 (left) and run 3 to 5 (right). Samples were diluted with water 1 to 5 prior to denaturation. The respective volume applied to the gel is specified in the figure. The numbers 1-4 indicate the bands used for in-gel digestion (see Section 4.2.1 and Appendix B.). 


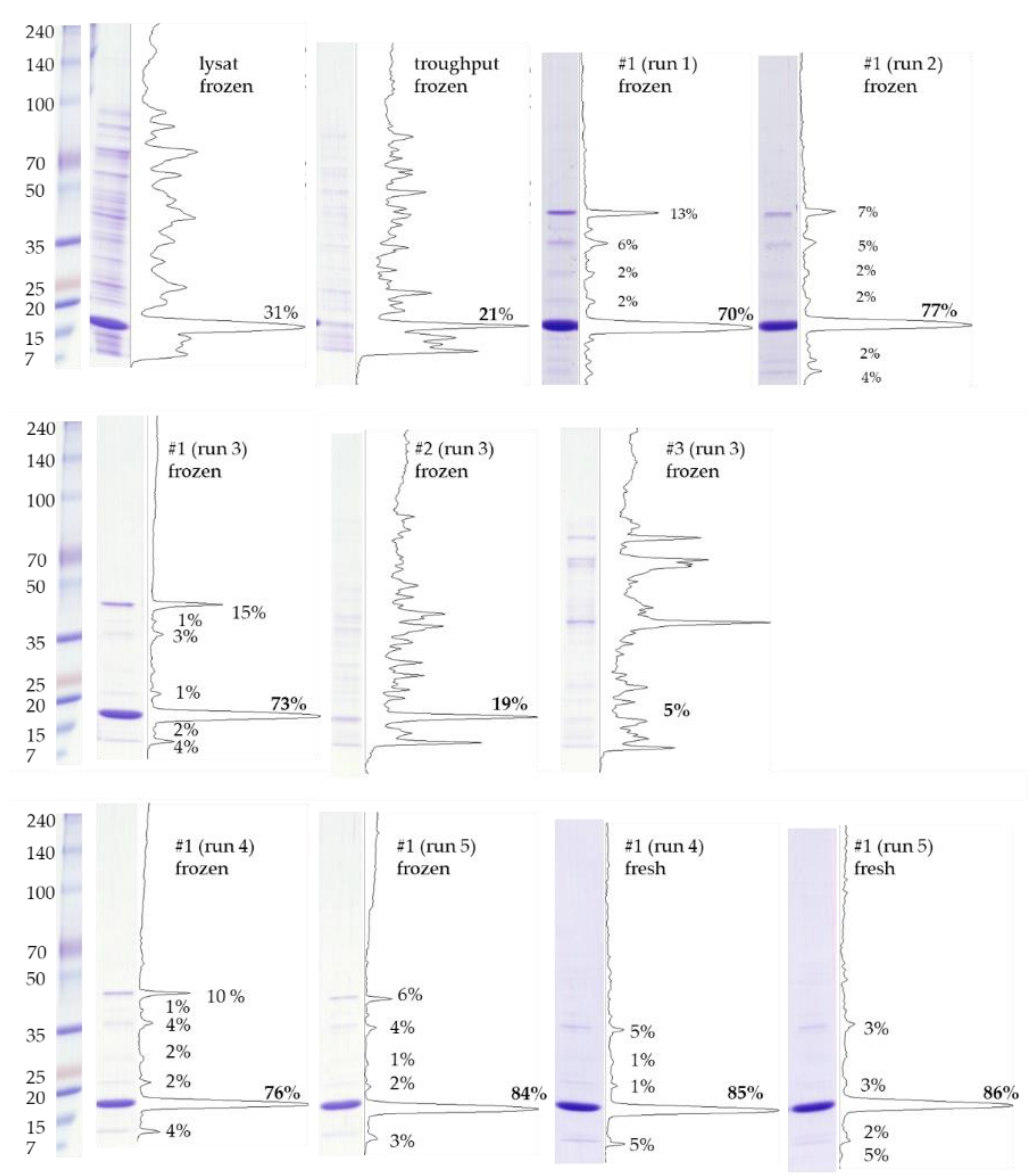

Figure 4. Purity of $\mathrm{r}-\mathrm{Mal} \mathrm{d} 1$ in pooled fractions estimated from stained SDS-PAGE gel analysis (Figure 3) by Fiji. The cut out of \#1 for run 4 and 5 is taken from the SDS-PAGE gel performed immediately after purification.

Avoiding dimerization during storage, the purity around $90 \%$ is sufficient for interaction studies (e.g., Isothermal Titration Calorimetry, Saturation Transfer Difference NMR experiments and SAR by NMR) if the impurity for each individual protein is below $5 \%$. For immunological studies often a purity $\geq 95 \%$ is suggested. However, distinct values for the Mal d 1 purity are not specified in the references cited. Nevertheless, further purification of the low Mal d 1 amounts required for these investigations might be easily performed by an additional HPSEC step.

\subsection{Characterization}

4.2.1. Verification of r-Mal d 1 and Characterization of an Impurity Formed during Storage by Mass Spectrometry after in Gel Digestion

Due to differences in the apparent molecular weight among the r-Mal d 1 and r-Mal $\mathrm{d}$ 1-His and the successive formation of a compound of higher molecular weight in-gel digestion followed by mass spectrometry is applied, to verify the identity of band 1 to 4 (Figure 3). The peptides generated by the tryptic digestion of band 1 and 2 as well as 3 and 4 indicate the expressed r-Mal d 1 as the primary protein (Figure 5). The sequence coverage is excellent for band 1 (r-Mal d 1, 100\%, run 1\#1), for band 3 (r-Mal d 1-His, 98\%), and good for band $2(88 \%$, run 2\#1). Based on the peptides found for band $4(98 \%)$, it is identified as an aggregate of r-Mal d 1-His, formed after the purification step during buffer exchange/concentration and storage. The formation of dimers under physiological conditions has been already mentioned by Roulias et al. Like Bet $v 1$, this group showed by SDS-PAGE that Mal d 1 tends to form oligomers with a size of $47 \mathrm{kDa}$ probably by 
disulfide-mediated aggregation. They determined a proportion of $34 \%$ dimers by High Pressure Size Exclusion Chromatography (HPSEC), which is comparable to our result.

(A)

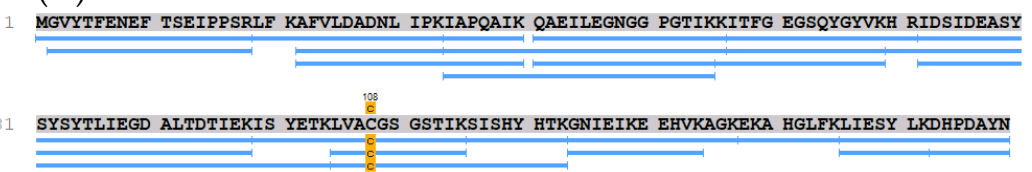

(B)

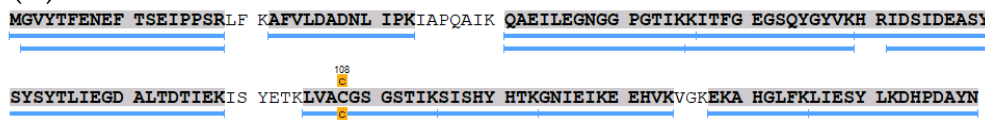

c. Carbamidomethylation $(+57.02)$

(C)

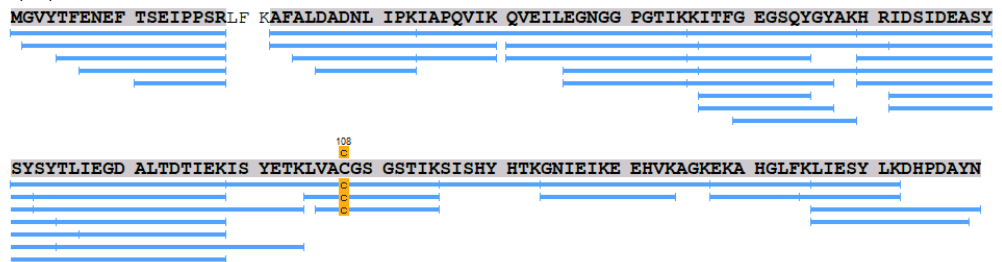

(D)
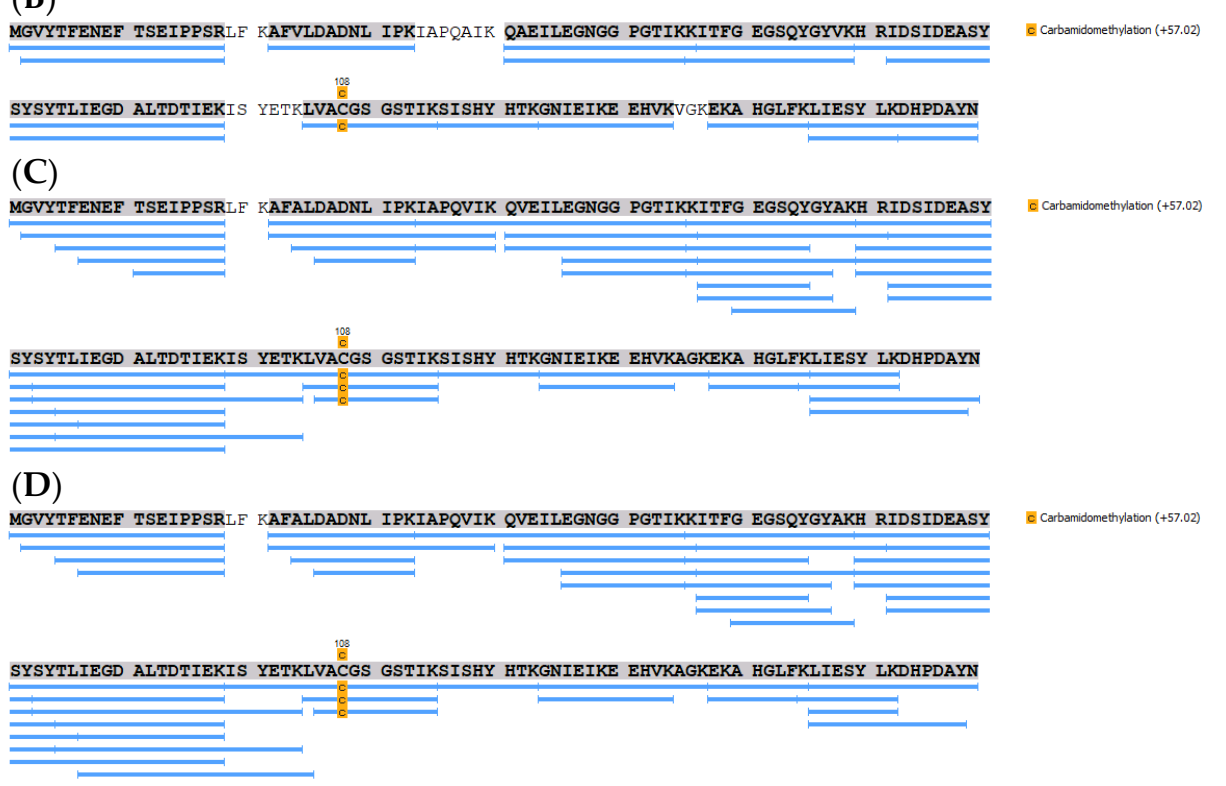

Figure 5. Sequence coverage determined by mass spectrometric of tryptic in-gel digests of bands excised from an SDS-PAGE (Figure 3 and Appendix C.). (A), band 1, run 1\#1, stored at $-20^{\circ} \mathrm{C}$; (B), band 2, run $2 \# 1$, stored at $-20^{\circ} \mathrm{C}$; (C) band 3 and (D) band 4, both belong to the IMAC fraction eluted with Tris buffer containing $10 \mathrm{mM}$ imidazole, which was concentrated and stored in urea buffer at $-20^{\circ} \mathrm{C}$.

\subsubsection{Verification of the Correct Folding by Circular Dichroism Spectroscopy}

The correct folding of r-Mal d 1 and r-Mal d 1-His is monitored by CD spectroscopy and secondary-structure elements are calculated (see Appendix D). CD spectra of r-Mal d 1 and r-Mal d 1-His are analogous (Figure 6). In accordance, their shape agrees with the spectra provided in the literature $[9,18]$. The analysis of the secondary structure results in $12 \% / 19 \% \alpha$-helices, 39\%/36\% $\beta$-sheet, $17 \% / 19 \%$ turn and 32\%/26\% random coil for $\mathrm{r}$-Mal d 1 and r-Mal d 1-His, respectively. These data conform to the secondary-structure information ( $25 \% \alpha$-helix, 35\% B-sheet) calculated from NMR spectra [2].

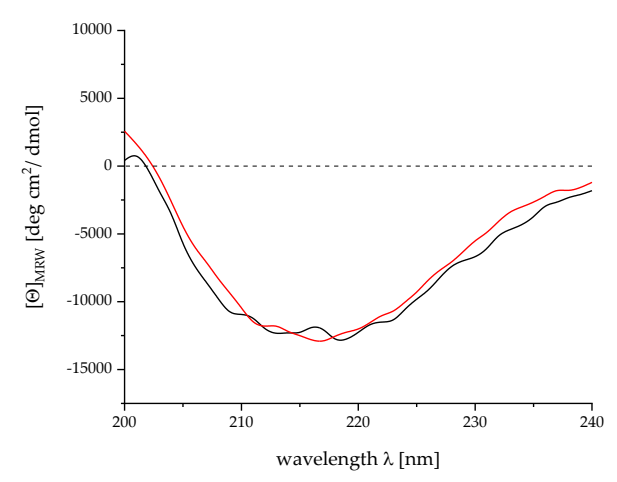

Figure 6. CD spectra for r-Mal d 1 (blue) versus r-Mal d1-His (orange). 


\subsubsection{Impact of Storage Conditions and Freeze-Thawing Process on Dimer Formation}

During storage at $-20{ }^{\circ} \mathrm{C}$ and the freeze-thawing process, purity decreased due to the formation of a new compound with higher molecular weight (Figures 3 and 4, run 3-5 \#1, frozen). Despite an apparent molecular weight above $34 \mathrm{kDa}$, this compound was characterized by mass spectrometry (see Section 3.3.1.) as a r-Mal d 1 dimer. In addition, by adding $10 \mathrm{mM}$ dithiothreitol (DTT) to the sample $10 \mathrm{~min}$ before denaturation, the band disappeared (Figure 6). With storage time, the dimer is probably formed by a disulfide bridge due to oxidation of the cysteine residues [18]. However, adding reducing agents during storage to prevent this dimerization is problematic because these substances might interfere in further experiments using the r-Mal $\mathrm{d} 1$.

To evaluate the impact of freeze and thawing effects, we simulated 10 cycles in a one-day experiment and observed dimer formation by SDS-PAGE gel analysis and CD spectroscopy. In addition, the process of freeze-drying of Mal d 1 in Tris buffer was studied (Figure 7).

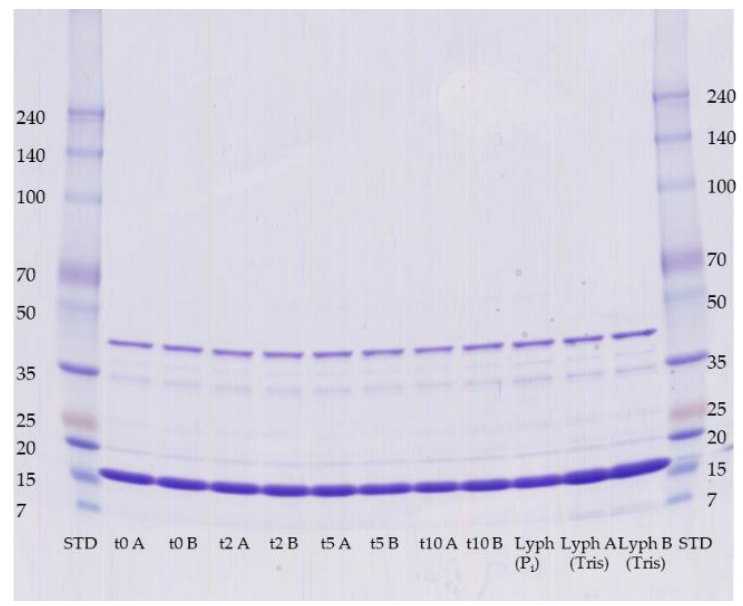

Figure 7. Impact of freeze-thawing and freeze-drying on the formation of the r-Mal $\mathrm{d} 1 \mathrm{dimer}$ for independent samples (A, B). Freeze-drying was performed with r-Mal d 1 in Tris buffer containing the $\mathrm{NaCl}$ as a residue of the ion-exchange chromatography and after re-buffering in phosphate buffer. Samples were diluted with water 1 to 5 prior to denaturation, the volume applied to the gel was $14 \mu \mathrm{L}$.

The impact of freeze-thawing (up to 10 times within one day) and freeze-drying was less relevant for the dimer formation with contents of $19 \pm 1 \%$ and $72 \pm 2 \%$ for the dimer and monomeric r-Mal d 1, respectively (Figure 6, purity evaluation not shown). In addition to the negligible impact of the freeze and thaw processes on dimer formation, no significant differences are observed in the respective CD spectra (Figure 8). The proportion of secondary-structure elements is constant within the standard deviations of independent measurements at the beginning (Table A1). 
(A)

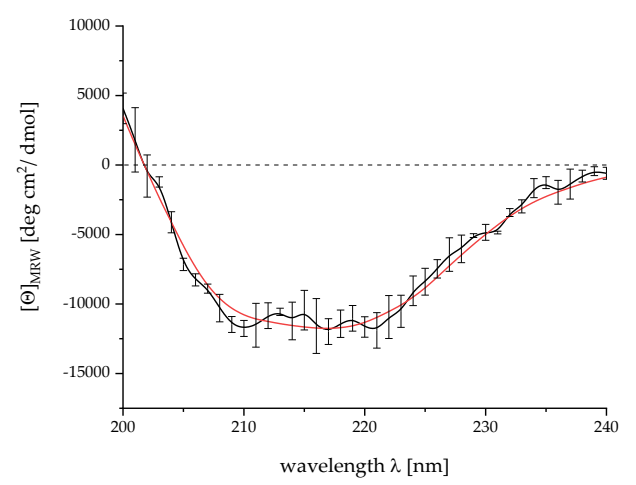

(B)

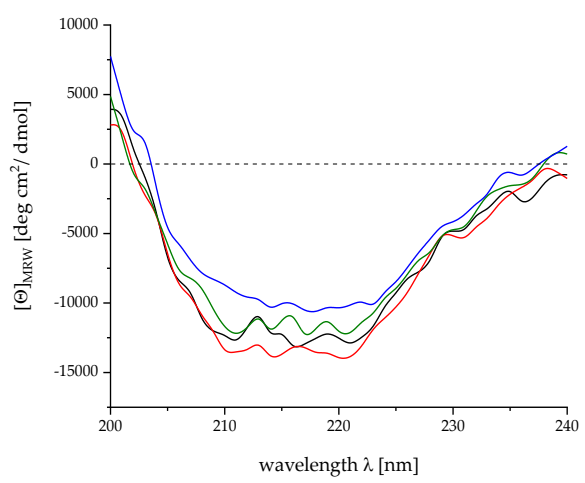

Figure 8. CD spectra for r-Mal d 1 for three independent measurements (A), data black, fit according to [21] in red) and at different cycles for freeze and thawing (B); 0, black; 2, green; 5, orange; 10, blue).

Dimer formation seems to increase with storage time (Figure 9) independently, whether in Tris or phosphate buffer. This effect was more pronounced for run 1 \#1 (longest storage time) than for all other runs. Urea buffer was detrimental, forcing the formation of dimers during storage. However, the addition of $10 \mathrm{mM}$ DTT (sample IMAC\#2(A)+DTT, Figure 9) to the sample $10 \mathrm{~min}$ before denaturation leads to the monomer of high purity. The process of freeze-drying does not increase dimer formation. However, CD spectra indicate that folding is affected (data not shown).

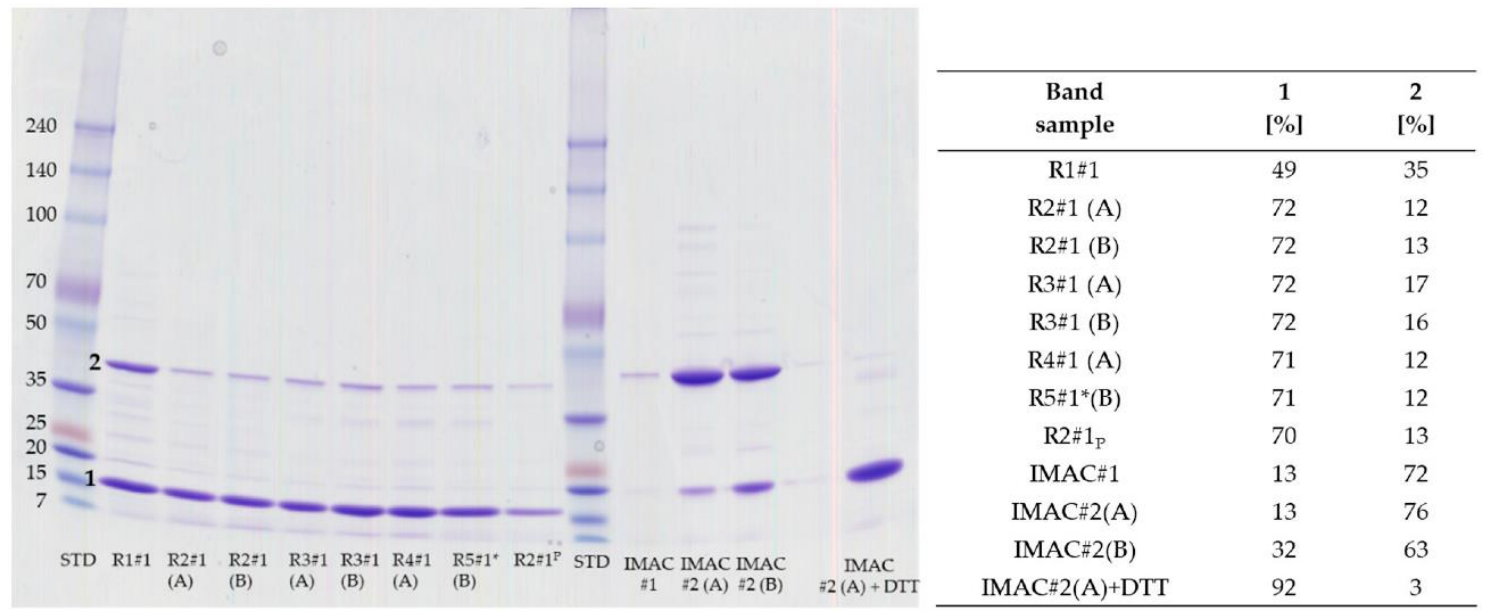

Figure 9. Impact of storage at $-20{ }^{\circ} \mathrm{C}$ in Tris buffer containing $100 \mathrm{mM} \mathrm{NaCl}$ and phosphate (Pi, $\left.\mathrm{R} 2 \# 1\right)$ and urea buffer (IMAC\#1 and \#2) on the formation of the r-Mal d 1 and r-Mal d 1-His (IMAC; \#1, 10 mM imidazole; \#2 100 mM imidazole) dimer. ${ }^{*}$ The sample volume used for the SDS-PAGE gel was doubled for run $5 \# 1$. The relative proportion for the monomer (1) and dimer (2) are determined from stained gels by Fiji.

Author Contributions: Conceptualization, M.B. and B.N.; methodology, B.N., S.M.R., J.A.H.K. and M.E.; investigation, J.A.H.K., S.M.R., M.E., B.N. and M.B.; resources, B.N. and M.B.; data curation, M.B., S.M.R. and M.E.; writing—original draft preparation, J.A.H.K. and M.B.; writing-review and editing, S.M.R., B.N., M.E.; visualization, J.A.H.K.; supervision, M.B.; project administration, M.B.; funding acquisition, M.B. All authors have read and agreed to the published version of the manuscript.

Funding: This research was funded by the German Research Foundation (DFG), grant number 3811/1-1 and by the Ministry of Science, Research and the Arts Baden-Württemberg (M.B., M. v. Wrangell program), the Leni Schöninger Foundation and funds of the chemical industry, Germany (FCI). 
Institutional Review Board Statement: Not applicable.

Informed Consent Statement: Not applicable.

Data Availability Statement: Data sharing is not applicable to this article.

Acknowledgments: We are grateful to Tosoh Bioscience GmbH (Griesheim, Germany) for the donation of the TOYOPEARL ${ }^{\mathrm{TM}}$ SuperQ-650S and GigaCap Q-650M SkillPak ${ }^{\mathrm{TM}}$. B. Hauer, is acknowledged for provision of the S1 lab infrastructure, J. Brockmeyer for access to the mass spectrometer and A. Jeltsch to the CD spectrometer and valuable assistance in data interpretation. Thanks to J. Bräcker for her advice performing the in-gel digestion.

Conflicts of Interest: The authors declare no conflict of interest.

\section{Appendix A}

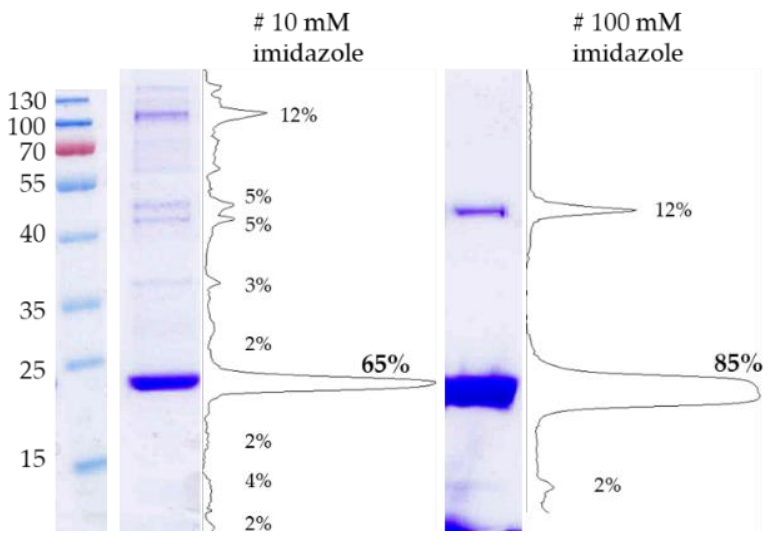

Figure A1. SDS-PAGE gel and determined purity for the pooled fractions eluted with Tris buffer containing $10 \mathrm{mM}$ (left) and $100 \mathrm{mM}$ imidazole (right).

\section{Appendix B. In-Gel Digestion}

In-gel digestion was carried out according to the protocol by Shevchenko et al. [22], with some modifications. The gel was rinsed with water for $10 \mathrm{~min}$, and bands 1 to 4 (Figure 3) were excised with a scalpel in pieces of $2 \times 2 \mathrm{~mm}$. The pieces were incubated with $500 \mu \mathrm{L}$ acetonitrile for $10 \mathrm{~min}$. The solvent was discharged, and reduction was performed at $56{ }^{\circ} \mathrm{C}$ for $30 \mathrm{~min}$ with $40 \mu \mathrm{L} 10 \mathrm{mM}$ DTT in $100 \mathrm{mM}$ ammonium hydrogen carbonate buffer. After cooling to room temperature, $500 \mu \mathrm{L}$ acetonitrile was added. After $10 \mathrm{~min}$ the solvent was removed and $40 \mu \mathrm{L} 55 \mathrm{mM}$ iodoacetamide in $100 \mathrm{mM}$ ammonium hydrogen carbonate buffer was added for alkylation. The samples were incubated for $20 \mathrm{~min}$ in the dark, followed by the addition of $500 \mu \mathrm{L}$ acetonitrile. The solvent was discharged, and the pieces were washed with $700 \mu \mathrm{L} 200 \mathrm{mM}$ ammonium hydrogen carbonate buffer/acetonitrile $(70 / 30 \mathrm{v} / v)$ at $37^{\circ} \mathrm{C}$ for $15 \mathrm{~min}$. This step was repeated until the pieces were decolorized. The pieces were dried using a vacuum concentrator $\left(30{ }^{\circ} \mathrm{C}, 1500 \mathrm{rpm}\right)$ for approx. $30 \mathrm{~min}$. Digestion of the protein was performed with $100 \mu \mathrm{L}$ of aqueous trypsin $(2 \mu \mathrm{g} / \mathrm{mL})$ at $37^{\circ} \mathrm{C}$ for $15 \mathrm{~min}$. The excess of tryptic solution was removed after $15 \mathrm{~min}$. The gel was incubated overnight at $37^{\circ} \mathrm{C}$ and then sonicated with $20 \mu \mathrm{L}$ water for $15 \mathrm{~min}$ to extract the peptides. After centrifugation for $30 \mathrm{~s}$ at $10,000 \times g$, the supernatant was mixed with $10 \mu \mathrm{L} \mathrm{H}_{2} \mathrm{O}$ /acetonitrile/formic acid $(91 / 9 / 0.3 v / v / v)$, mimicking chromatographic starting condition and subjected to HPLC-MS/MS analysis.

\section{Appendix C. Mass Spectrometric Identification}

The tryptic in gel digests were separated by reversed-phase liquid chromatography on a YMC-Triart C18 column using an M3 MicroLC system at $40{ }^{\circ} \mathrm{C}$ and a flow rate of $7 \mu \mathrm{L} / \mathrm{min}$. After injection of $5 \mu \mathrm{L}$, the peptides were eluted with aqueous formic acid (A, $\mathrm{H}_{2} \mathrm{O} /$ formic acid 99.9/0.1 v/v) and formic acid in acetonitrile (B, acetonitrile/ formic acid 
$99 / 0.1 \mathrm{v} / \mathrm{v}$ ). Starting with $3 \%$, B was raised to $8 \%$ in $2 \mathrm{~min}$, increased to $30 \%$ from 2 to $68 \mathrm{~min}$ and to $40 \%$ from 68 to $73 \mathrm{~min}$. Then B was increased to $80 \%$ in $3 \mathrm{~min}$ and maintained at $80 \%$ for $3 \mathrm{~min}$ until it was decreased to $3 \%$ in $1 \mathrm{~min}$ and reconditioning for $8 \mathrm{~min}$. LC-MS analyses were carried out on a quadrupole TOF mass spectrometer (TripleTOFTM 6600, SCIEX). Acquisitions were performed using Analyst ${ }^{\circledR}$ TF 1.7 software (SCIEX). Standard DDA (data dependent acquisition) runs were performed and the data analyzed with PEAKS X+ (https://www.bioinfor.com/peaks-studio) matching the peptides with the data for Mal d 1 found in UniProt [https:/ / www.uniprot.org/] and the sequence for the modified plasmid insert.

\section{Appendix D. CD Spectroscopy}

Circular dichroisms spectroscopy was carried out with a JASCO-J815 spectrophotometer using a quartz cuvette of $0.1 \mathrm{~cm}$ path length. Far UV (200 to $240 \mathrm{~nm})$ spectra with approx. $0.1 \mathrm{mg} / \mathrm{mL}$ protein in $100 \mathrm{mM}$ phosphate buffer $\mathrm{pH} 7.5$, diluted with $200 \mathrm{mM}$ $\mathrm{KCl}(1 / 3 \mathrm{v} / \mathrm{v})$ were recorded at $20^{\circ} \mathrm{C}$ with $1 \mathrm{~nm}$ band width, $1 \mathrm{~s}$ response time and $1 \mathrm{~nm}$ data pitch. A total of 40 consecutive scans were averaged, and the baseline as the average of blank samples was subtracted from the spectra. Data are presented as mean residue molar ellipticity $(\Theta)$, and secondary-structure elements are calculated based on Provenchur and Glöckner (1981) [21]. Molar ellipticity is calculated according equation 1 by the use of $9.91 \mu \mathrm{M}$ protein concentration, $0.1 \mathrm{~mm}$ for path length and $n=159$ and 165 for the r-Mal d1 and r-Mal d1-His, respectively.

$$
[\Theta]\left(\operatorname{deg} \cdot \mathrm{cm}^{2} \cdot \mathrm{dmol}^{-1}\right)=\frac{\text { ellipticity }(\text { mdeg }) \cdot 10^{6}}{\text { path length }(\mathrm{mm}) \cdot[\text { protein }](\mu \mathrm{M}) \cdot(n-1)}
$$

Table A1. Variation of secondary structure elements of purified r-Mal d 1 for independent samples ${ }^{1}$ and alterations during the freeze and thaw process ${ }^{2}$.

\begin{tabular}{cccccccccc}
\hline Secondary Structure Element [\%] & $\mathbf{t}_{\mathbf{0}} \mathbf{A}$ & $\mathbf{t}_{\mathbf{0}} \mathbf{B}$ & $\mathbf{t}_{\mathbf{0}} \mathbf{B}^{\mathbf{3}}$ & $\mathbf{t}_{\mathbf{2}} \mathbf{B}$ & $\mathbf{t}_{\mathbf{5}} \mathbf{A}$ & $\mathbf{t}_{\mathbf{5}} \mathbf{B}$ & $\mathbf{t}_{\mathbf{1 0}} \mathbf{A}$ & Average & $\mathbf{S D}$ \\
\hline$\alpha$-helix & 17 & 17 & 18 & 20 & 19 & 17 & 17 & 17.9 & 1.1 \\
$\beta$-sheet & 37 & 37 & 36 & 35 & 36 & 37 & 38 & 36.6 & 0.9 \\
$\quad$ turn & 19 & 19 & 19 & 19 & 19 & 19 & 21 & 19.3 & 0.7 \\
random & 28 & 27 & 26 & 26 & 27 & 27 & 24 & 26.4 & 1.2 \\
\hline
\end{tabular}

${ }^{1}$ independent Mal d 1 dilutions A and B prior to the freeze and thaw process; ${ }^{2}$ sample was frozen and subsequently thaw for 2,5 and 10 times; ${ }^{3} \mathrm{t}_{0} \mathrm{~B}$ repeated measurement after sample storage at $7{ }^{\circ} \mathrm{C}$ overnight.

\section{References}

1. Hoffmann-Sommergruber, K. The SAFE project: 'Plant food allergies: Field to table strategies for reducing their incidence in Europe' an EC-funded study. Allergy 2005, 60, 436-442. [CrossRef] [PubMed]

2. Ahammer, L.; Grutsch, S.; Kamenik, A.S.; Liedl, K.R.; Tollinger, M. Structure of the Major Apple Allergen Mal d 1. J. Agric. Food Chem. 2017, 65, 1606-1612. [CrossRef] [PubMed]

3. Ahammer, L.; Grutsch, S.; Tollinger, M. NMR resonance assignments of the major apple allergen Mal d 1. Biomol. NMR Assign. 2016, 10, 287-290. [CrossRef] [PubMed]

4. Holm, J.; Ferreras, M.; Ipsen, H.; Würtzen, P.A.; Gajhede, M.; Larsen, J.N.; Lund, K.; Spangfort, M.D. Epitope grafting, re-creating a conformational Bet $\mathrm{v} 1$ antibody epitope on the surface of the homologous apple allergen Mal d 1. J. Biol. Chem. 2011, 286, 17569-17578. [CrossRef] [PubMed]

5. Bergmann, K.-C. Beobachtungsstudie zur Apfelallergie am Allergie-Centrum der Berliner Charité für die Europäische Stiftung für Allergieforschung (ECARF) 1017. Available online: https:/ /www.ecarf.org/presse/studie-alte-apfelsorten-lindern-allergie/ (accessed on 27 December 2020).

6. Jenkins, J.A.; Griffiths-Jones, S.; Shewry, P.R.; Breiteneder, H.; Mills, E.N.C. Structural relatedness of plant food allergens with specific reference to cross-reactive allergens: An in silico analysis. J. Allergy Clin. Immunol. 2005, 115, 163-170. [CrossRef] [PubMed]

7. Oberhuber, C.; Ma, Y.; Marsh, J.; Rigby, N.; Smole, U.; Radauer, C.; Alessandri, S.; Briza, P.; Zuidmeer, L.; Maderegger, B.; et al. Purification and characterisation of relevant natural and recombinant apple allergens. Mol. Nutr. Food Res. 2008, 52 (Suppl. 2), S208-S219. [CrossRef] 
8. Vlieg-Boerstra, B.J.; van de Weg, W.E.; van der Heide, S.; Kerkhof, M.; Arens, P.; Heijerman-Peppelman, G.; Dubois, A.E.J. Identification of low allergenic apple cultivars using skin prick tests and oral food challenges. Allergy 2011, 66, 491-498. [CrossRef]

9. Bolhaar, S.T.H.P.; van de Weg, W.E.; van Ree, R.; Gonzalez-Mancebo, E.; Zuidmeer, L.; Bruijnzeel-Koomen, C.A.F.M.; FernandezRivas, M.; Jansen, J.; Hoffmann-Sommergruber, K.; Knulst, A.C.; et al. In vivo assessment with prick-to-prick testing and double-blind, placebo-controlled food challenge of allergenicity of apple cultivars. J. Allergy Clin. Immunol. 2005, 116, 1080-1086. [CrossRef]

10. Matthes, A.; Schmitz-Eiberger, M. Apple (Malus domestica L. Borkh.) allergen Mal d 1: Effect of cultivar, cultivation system, and storage conditions. J. Agric. Food Chem. 2009, 57, 10548-10553. [CrossRef]

11. Asero, R.; Marzban, G.; Martinelli, A.; Zaccarini, M.; Machado, M.L.d.C. Search for low-allergenic apple cultivars for birch-pollenallergic patients: Is there a correlation between in vitro assays and patient response? Eur. Ann. Allergy Clin. Immunol. 2006, 38, 94-98.

12. Romer, E.; Chebib, S.; Bergmann, K.-C.; Plate, K.; Becker, S.; Ludwig, C.; Meng, C.; Fischer, T.; Dierend, W.; Schwab, W. Tiered approach for the identification of Mal d 1 reduced, well tolerated apple genotypes. Sci. Rep. 2020, 10, 9144. [CrossRef] [PubMed]

13. Garcia, A.; Wichers, J.H.; Wichers, H.J. Decrease of the IgE-binding by Mal d 1, the major apple allergen, by means of polyphenol oxidase and peroxidase treatments. Food Chem. 2007, 103, 94-100. [CrossRef]

14. Kiewning, D.; Wollseifen, R.; Schmitz-Eiberger, M. The impact of catechin and epicatechin, total phenols and PPO activity on the Mal d 1 content in apple fruit. Food Chem. 2013, 140, 99-104. [CrossRef] [PubMed]

15. Kschonsek, J.; Dietz, A.; Wiegand, C.; Hipler, U.-C.; Böhm, V. Allergenicity of apple allergen Mal d 1 as effected by polyphenols and polyphenol oxidase due to enzymatic browning. LWT 2019, 113, 108289. [CrossRef]

16. Haka, J.; Niemi, M.H.; Iljin, K.; Reddy, V.S.; Takkinen, K.; Laukkanen, M.-L. Isolation of Mal d 1 and Api g 1—Specific recombinant antibodies from mouse IgG Fab fragment libraries-Mal d 1-specific antibody exhibits cross-reactivity against Bet v 1. BMC Biotechnol. 2015, 15, 34. [CrossRef] [PubMed]

17. Ma, Y.; Gadermaier, G.; Bohle, B.; Bolhaar, S.; Knulst, A.; Markovic-Housley, Z.; Breiteneder, H.; Briza, P.; HoffmannSommergruber, K.; Ferreira, F. Mutational analysis of amino acid positions crucial for IgE-binding epitopes of the major apple (Malus domestica) allergen, Mal d 1. Int. Arch. Allergy Immunol. 2006, 139, 53-62. [CrossRef]

18. Roulias, A.; Pichler, U.; Hauser, M.; Himly, M.; Hofer, H.; Lackner, P.; Ebner, C.; Briza, P.; Bohle, B.; Egger, M.; et al. Differences in the intrinsic immunogenicity and allergenicity of Bet v 1 and related food allergens revealed by site-directed mutagenesis. Allergy 2014, 69, 208-215. [CrossRef]

19. van Die, I.M.; Bergmans, H.E.; Hoekstra, W.P. Transformation in Escherichia coli: Studies on the role of the heat shock in induction of competence. J. Gen. Microbiol. 1983, 129, 663-670. [CrossRef]

20. Schindelin, J.; Arganda-Carreras, I.; Frise, E.; Kaynig, V.; Longair, M.; Pietzsch, T.; Preibisch, S.; Rueden, C.; Saalfeld, S.; Schmid, B.; et al. Fiji: An open-source platform for biological-image analysis. Nat. Methods 2012, 9, 676-682. [CrossRef]

21. Provencher, S.W.; Glöckner, J. Estimation of globular protein secondary structure from circular dichroism. Biochemistry 1981, 20, 33-37. [CrossRef]

22. Shevchenko, A.; Tomas, H.; Havlis, J.; Olsen, J.V.; Mann, M. In-gel digestion for mass spectrometric characterization of proteins and proteomes. Nat. Protoc. 2006, 1, 2856-2860. [CrossRef] [PubMed] 